\title{
Effect of Vetiver Grass (Vetiver Zizanodes) Hedgerows on Selected Soil Properties and Crop Yield on Farm Land at Haru District, Western Ethiopia
}

\author{
Leta Hailu $^{1 *}$, Gizaw Tesfaye ${ }^{2}$, Tesfaye Yaekob ${ }^{3}$ \\ 1,2,3 Jimma Agricultural Research Center, Jimma, Ethiopia.
}

*Corresponding Authors: Leta Hailu, Jimma Agricultural Research Center, Jimma, Ethiopia.

\begin{abstract}
The objective of the study was to evaluate the effect of Vetiver grass hedgerows on selected soil properties and crop production at Haru, western Ethiopia. Composite soil samples were collected from crop land treated with seven years aged Vetiver grass hedgerows and adjacent untreated cropland. The soil samples were analyzed following standard laboratory procedure for selected soil property variation. The result of the analysis showed that Soil Organic Carbon $(P<0.012)$ and Available Phosphorus $(P<0.046)$ was significantly higher for cropland treated with Vetiver grass hedgerows than adjacent untreated cropland. However, soil $\mathrm{pH}$, Exchangeable acidity, Available Potassium and Total Nitrogen were not exhibited significant variation among the croplands. Mean Crop yield was also shown higher under cropland treated with Vetiver hedgerows as compared to adjacent untreated cropland. The average slope of the treated cropland with Vetiver grass hedgerows was reduced by $7 \%$ as compared to adjacent untreated cropland. The study concluded that the established Vetiver hedgerows had positively affected some soil properties, crop yield and slope of the specific site. Therefore, Vetiver hedgerows should be established and managed on farm lands to reduce soil erosion and improve land productivity. This study also recommends further investigation on the potential of the grass on different landscape position and carbon sequestration.
\end{abstract}

Keywords: Cropland, Soil properties, Vetiver grass hedgerow

\section{INTRODUCTION}

In Ethiopia, land degradation due to soil erosion is the most serious ecological process threatening the agricultural production and food security of the country [1,2]. The study conducted in various part of the country reveals that the rate of annual soil loss is varied based on local land use practices, vegetation coverage, soil type, topography and agro-ecology of the specific area. For instance, the soil loss was $14.8 \mathrm{t} \mathrm{ha}^{-1} \mathrm{yr}^{-1}$, in Tigray highlands [3]; $30.2 \mathrm{t} \mathrm{ha}^{-1} \mathrm{yr}^{-1}$ for Koga River [4] and extends up to $237 \mathrm{t} \mathrm{ha}^{-1}$ year $^{-1}$ in steep area of the Geleda watershed of the Blue Nile basin [5]. According to [6], $65.9 \mathrm{Mg} \mathrm{ha}^{-1} \mathrm{yr}^{-1}$ soil was lost under cultivation land in North-eastern Wollega. The mean annual soil loss of the Somodo watershed, South West Ethiopia, was 18.69 ton $^{-1}$ year $^{-1}$ ranging from 0 to 131.21 ton $^{-1}$ year $^{-1}$ [7]. Preliminary soil loss and run-off studies at Melko (Jimma Agricultural Research Center) also indicate 82.3 ton ha ${ }^{-1}$ soil was eroded annually [8]. These all indicate the soil loss exceeds tolerable level of annual soil loss of 11 tons $\mathrm{ha}^{-1} \mathrm{yr}^{-1}[9,10]$.

Furthermore, the loss of soil also results in loss of water, nutrients, soil organic matter, and soil biota that affects the proper functioning of the soil system. Biological Soil and water conservation reduce erosion and improves soil carbon that enhances restoration of degraded land. The practices are viable to improve the soil system and sustain the ecological functioning of the soil [11]. However, efforts to control land degradation is mainly focused on physical conservation structures alone throughout the history, which have less contribution to add the removed nutrients and control soil erosion $[12,13]$. Vetiver grass is a perennial grass, economically viable and environmentally adaptable grass with unique characteristics that grows in wide range of agro-ecology across the world [14, 15]. Its unique characteristics and a wide range of environmentally adaptability make it best grass for hedgerow establishment to control erosion and as stabilizer of structure when integrated with physical soil and water conservation measures [16, 17]. Vetiver grass technology is promoted for soil and water conservation by World Bank in India first time in mid-1980 [18, 19]. 
In Ethiopia, Vetiver grass was for the first time introduced in 1971E.C from Tanzania to Jimma research station. The grass was distributed out of the research station to the nearby coffee state farms and to Menschen für Menschen (MfM) for the first time in 1984/85 with the objective of utilizing as mulch and soil and water conservation practice. The first nursery was established in the early 90's by MfM in the southwestern part of the country. Then after, it was distributed to different Woreda's and research centers for soil erosion control [20]. Degraded environment as a result of improper land use practice such as the Ethiopian highlands can be improved using Vetiver grass hedgerows [21].

Vetiver grass was lately introduced in Western parts of Ethiopia comparably, and its effect for landscape, soil properties and land and/or crop production is not studied yet in the area. For these purpose Vetiver grass hedgerows were established on farm lands by community participation at Haru district in 2011G.C for evaluation of soil and water conservation. Therefore, the objective of the study was to evaluate the potential of Vetiver grass for crop production and its effect on selected soil physical and chemical properties.

\section{Methods AND Materials}

\subsection{Description of the Study Area}

The study was conducted in Haru district, West Wollega Zone of Oromia Regional State of Ethiopia. The district is located at a distance of $466 \mathrm{~km}$ from Addis Ababa to western Ethiopia. It is geographically located between 8052'00' $\mathrm{N}-9 \mathrm{o} 33^{\prime} 00^{\prime} \mathrm{N}$ latitude and $35^{\circ} 40^{\prime} 00^{\prime \prime} \mathrm{E}-36^{\circ} 00^{\prime} 00^{\prime}$ 'E longitude [Figure 1]. The mean annual rainfall is $1700 \mathrm{~mm}$ and minimum and maximum temperature of the district is $12^{\circ} \mathrm{C}$ and $27^{\circ} \mathrm{C}$, respectively. The topography of the study area is undulating hills slightly sloping down having an altitude range from $1500 \mathrm{~m}$ to $2050 \mathrm{~m}$ a.s.l. Haru district has 46,451.91 ha total cultivable land [22].
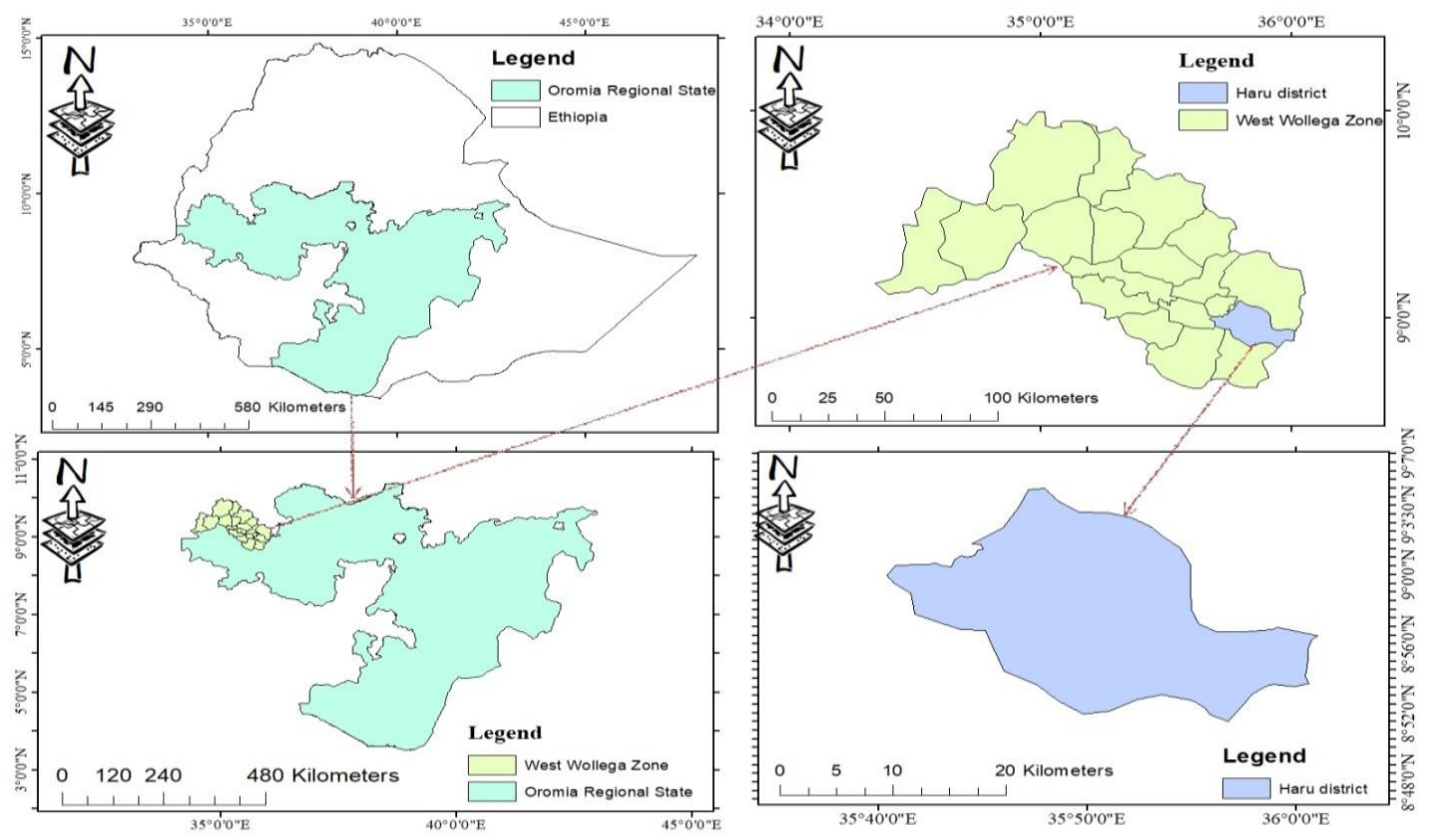

Figure1. Map of Haru district, Western Wollega zone, Ethiopia

Population: The total populations of the Haru district is 67,262 of which are 33,178 are males and 34,084 are females [23].

Farming system: The mixed farming system that involves crop production and animal husbandry is the predominant farming practice in the study area. The main crops grown in the study area are Maize (Zea mays), sorghum (Sorghum bicolor) and teff (Eragrosties tef zucca) and cash crops like coffee (Coffee Arabica), khat, and fruits like Mango, Avocado, papaya etc. The major livestock reared are cattle, poultry, sheep and goat. Oxen power is the main power source for ploughing and threshing activities in the study area [24].

Research design and soil sampling: Reconnaissance survey was conducted to identify farmland for intervention. Accordingly, farm land was identified based on the prevalence of soil erosion, 
accessibility and slope from a Kombocha Yonge kebele of Haru district. A total of 2-3 tillers of Vetiver grass were planted along the contours in double rows with staggered positions with $20 \mathrm{~cm}$ inter and intra row spacing. Vertical interval (VI) was used for determining the spacing between consecutive Vetiver hedgerows. Adjacent cropland was left as a control to compare for soil properties variation, monitor slope change and yield variation. Composite soil samples from depth $(0-30 \mathrm{~cm})$ were collected from cropland treated with Vetiver hedgerows and adjacent cropland without Vetiver grass hedgerows. A total of 24 composite soil samples were collected for analysis of selected soil chemical properties. The selection of the companion crops and cropping systems was based on the local practice of the area.

Laboratory analyses: Soil $\mathrm{pH}$ was determined by a water suspension method with microprocessor based $\mathrm{pH}$ system on a 1:2.5 soil to water ratio [25]. Bray II extraction method with spectrophotometer analysis [26] was used for available phosphorus (Av.-P) determination. Organic carbon (OC) was determined by Walkley and black method [27]. Kjeldahl digestion, distillation and titration method [28] was used for total $\mathrm{N}$ determination. Exchangeable acidity was determined by saturating the soil samples with a potassium chloride solution and titrates with sodium hydroxide as described by [29]. Available potassium (K) was analyzed by flame photometer as described by [30].

\section{RESULTS AND DISCUSSION}

\section{EFFECT OF VETIVER GRASS HEDGEROWS ON SELECTED SOIL PROPERTIES}

The result of the analysis showed that soil $\mathrm{pH}$ was not significantly different between the cropland with Vetiver grass hedgerows and adjacent cropland without Vetiver grass hedgerows. However, higher mean of soil $\mathrm{pH}$ was observed under the cropland treated with Vetiver grass hedgerows (Table 1). This might be due to inherent soil properties and the condition of previous land management that affect the soil $\mathrm{pH}$. According to the rating criteria suggested by [31] for soils of Ethiopian highlands; the soil $\mathrm{pH}$ of the site was rated as moderately acidic (5.1- 6.0). Exchangeable acidity was not exhibited significant variation between treated cropland with Vetiver grass hedgerows and adjacent cropland without Vetiver grass hedgerows [Table 1]. This might be due to leaching of basic cations. In contrary to the present result, [7] reported that exchangeable acidity was higher above Vetiver grass hedgerows on study conducted in Somodo watershed. Available phosphorus was significantly varied between cropland treated with Vetiver grass hedgerows and adjacent cropland without Vetiver grass hedgerows. The higher mean was observed under cropland treated with Vetiver grass hedgerows [Table 1]. Clearly, this due to deposition of fertile top soil and crop residue input on conserved cropland with Vetiver grass hedgerows. According to [32], available phosphorus was significantly different for plots with Vetiver grass than without Vetiver grass at the Anno Agro Industry Farm. Similarly, [7] also reported that available phosphorus was higher above Vetiver hedgerows due to soil deposition as impeded by Vetiver grass hedgerows at Somodo watershed.

In contrary to the present finding [33] report that established Vetiver hedgerows were showed reduction in available phosphorous after the second year of intervention. This might be due to previous land use practices. Available potassium was not significantly different between cropland treated with Vetiver grass hedgerows and adjacent cropland without Vetiver grass hedgerows. Though, the higher mean was recorded under cropland treated with Vetiver grass hedgerows [Table 1]. In Contrasting to the current finding, [32] reported that available potassium was significantly higher for the plot with Vetiver hedgerows than without Vetiver grass hedgerows.

Soil organic carbon was demonstrated significant difference among croplands treated with Vetiver grass hedgerows and adjacent cropland without Vetiver grass hedgerows. The higher mean of soil organic carbon was observed under cropland conserved with Vetiver grass hedgerows [Table 1]. Apparently, this was due to reduced removal of fertile topsoil and organic matter input from crop residues. This effect coupled with the addition of both above ground and below ground biomass of Vetiver grass and crop residue on conserved cropland as favored by conserved soil moisture on cropland treated with Vetiver grass hedgerows. The result was in line with finding of [32] in which organic matter was significantly higher for cropland with Vetiver grass strips than plot without Vetiver grass hedgerows.

According to [Table 1] total nitrogen did not indicated significant variation between cropland treated with Vetiver grass hedgerows than adjacent cropland without Vetiver grass hedgerows. Soil organic 
Effect of Vetiver Grass (Vetiver Zizanodes) Hedgerows on Selected Soil Properties and Crop Yield on Farm Land at Haru District, Western Ethiopia

carbon was significantly higher for cropland treated with Vetiver grass hedgerows, while soil organic matter and total nitrogen is positively correlated and soil organic carbon serve as a source for different soil nutrients. The result was in contrast to [32] who indicated total nitrogen was significantly different for soil with Vetiver grass than for plot without Vetiver grass.

\section{Effect of Veritver hedgerows on slope of farm land}

Vetiver hedgerows of seven years aged were influenced slope of the farm land. The slope of cropland treated with Vetiver hedgerows was reduced by $7 \%$ as compared to adjacent cropland without Vetiver hedgerows [Figure 2]. The established Vetiver hedgerows were also affected steepness and length of slope of the cropland and the inter hedgerows were developed to bench terrace due to accumulation of eroded soil above the hedgerows [Plate 1]. This indicate the contribution of Vetiver grass hedgerows to reduce runoff velocity as a result it reduces the losses of the soil, nutrients and water; hence improve productive capacity of the farmland. The result was in agreement with the finding of [7] that two years aged Vetiver grass hedgerows were reduced slope of the field on average by $2.5 \%$ due to soil accumulated above Vetiver hedgerows.

\section{Effect of seven years Vetiver grass hedgerows on crop productivity at Haru, Western Ethiopia.}

At kombolcha Yonge kebele, seven years aged Vetiver hedgerows were evaluated with adjacent cropland without Vetiver grass hedgerows on the productivity of the land for the cropping season of 2014 and 2015. The yield of the teff (Eragrosties tef zucca) was not showed significant variation under cropland treated with Vetiver grass hedgerows and adjacent cropland without Vetiver hedgerows [Table 2]. However, higher mean yield was observed under cropland with Vetiver hedgerows. This clearly demonstrated the effect of Vetiver grass hedgerows that reduce soil erosion and organic matter input on conserved cropland than adjacent cropland without Vetiver grass hedgerows that improves productivity of the cropland. A similar pattern was reported by [34] that crop yields were improved by a range of $11-26 \%$ and $50 \%$ for cowpea and maize, respectively on study conducted in Ibadan, Nigeria.

Table1. Effect of Vetiver grass hedgerows on selected soil chemical properties of top soil layer (0-30cm) at Haru, Western Ethiopia

\begin{tabular}{|l|l|l|l|l|l|l|}
\hline Treatments & \multicolumn{9}{|l|}{ Parameters } & \begin{tabular}{l} 
Av.P \\
\cline { 2 - 8 }
\end{tabular} & $\begin{array}{l}\mathrm{pH} \\
\left(\mathrm{H}_{2} \mathrm{O}\right. \\
\end{array}$ & $\begin{array}{l}\text { Ex.acidity } \\
(\mathrm{meq} / 100 \mathrm{gm})\end{array}$ & $\begin{array}{l}\text { Ava.K } \\
(\mathrm{meq} / 100 \mathrm{gm})\end{array}$ & $\begin{array}{l}\text { SOC } \\
(\%)\end{array}$ & $\begin{array}{l}\text { TN } \\
(\%)\end{array}$ \\
\hline $\begin{array}{l}\text { Vetiver } \\
\text { hedgerow }\end{array}$ & 5.27 & 0.19 & 10.20 & 0.17 & 1.61 & 0.14 \\
\hline $\begin{array}{l}\text { Without Vetiver } \\
\text { hedgerows }\end{array}$ & 5.11 & 0.19 & 4.22 & 0.16 & 0.19 & 0.15 \\
\hline CV $(\%)$ & 1.01 & 3.82 & 18.5 & 15.93 & 18.95 & 19.51 \\
\hline LSD & 0.22 & 0.03 & 5.73 & 0.11 & 0.73 & 0.12 \\
\hline
\end{tabular}

pH: soil pH, Av.P: available phosphorus: SOC: Soil organic carbon, TN: total nitrogen

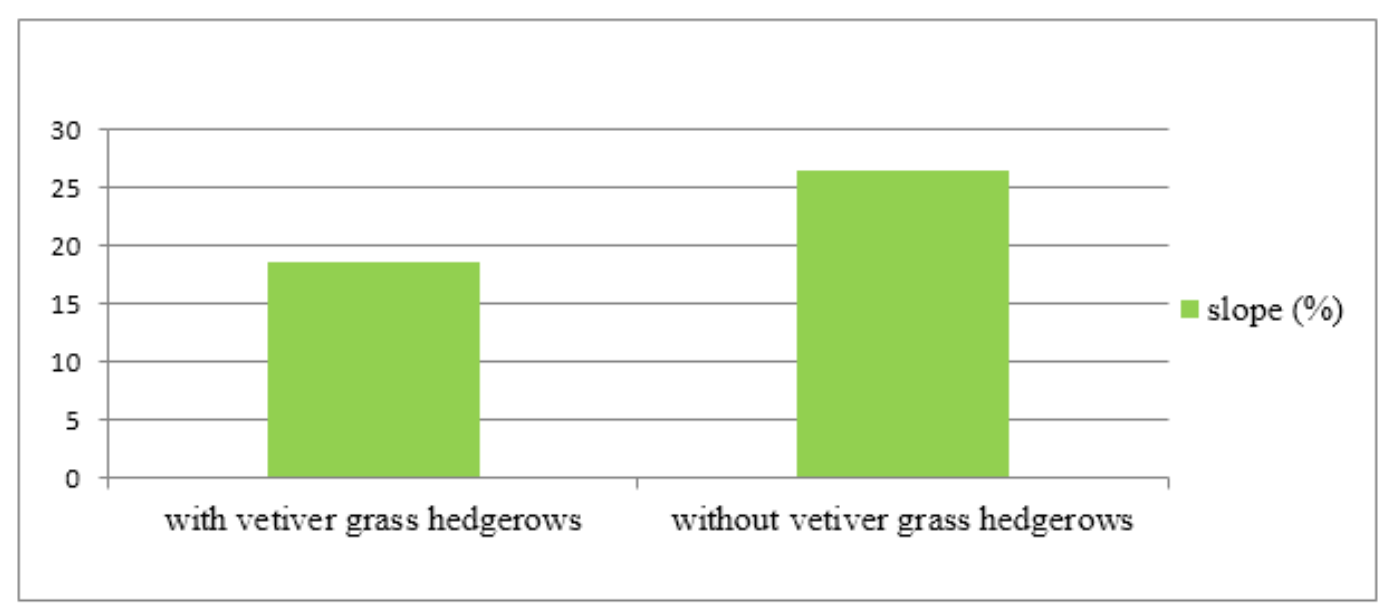

Figure2. Effect of Vetiver hedgerows on slope of the farm land at Haru. 
Plate1. Effect of Vetiver grass hedgerows on slope of farm land

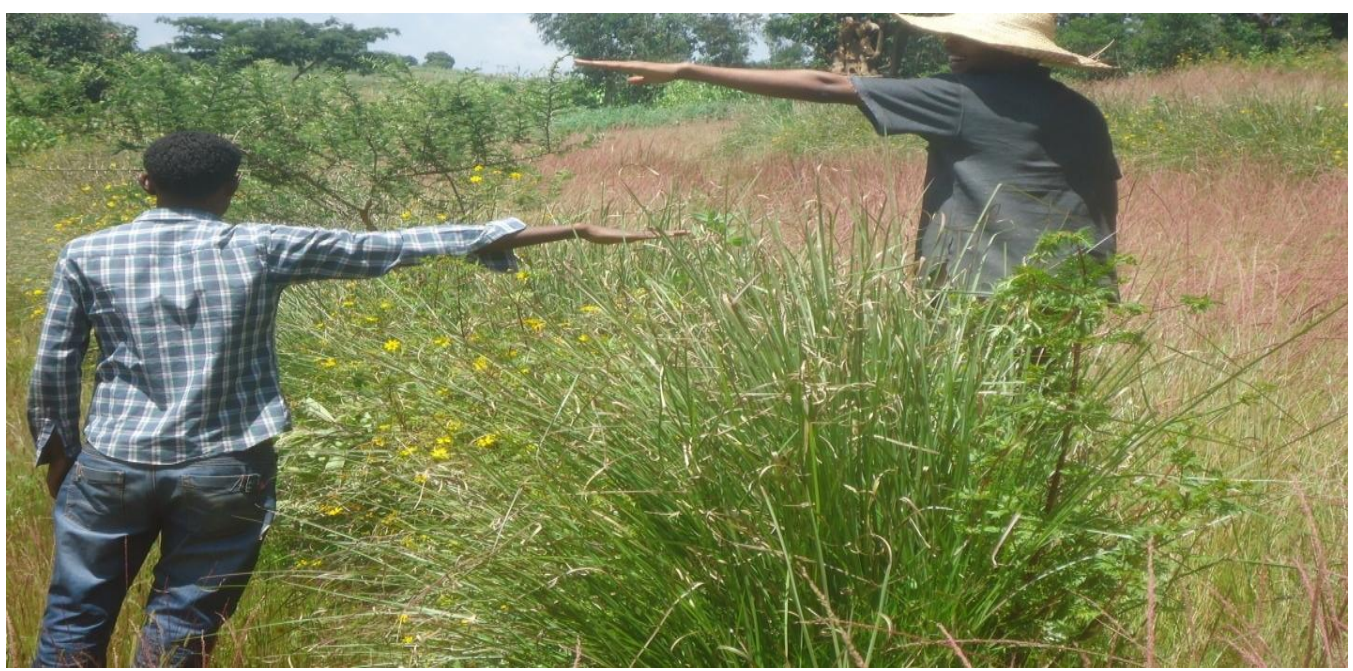

Source: photo taken during field observation

Table2. Effect of Vetiver grass hedgerows on teff(Eragrosties tef zucca) yield

\begin{tabular}{|l|l|}
\hline \multicolumn{1}{|c|}{ Treatments } & Yield $(\mathrm{kg} / \mathrm{ha})$ \\
\hline With Vetiver grass hedgerows & 850.8 \\
\hline Without Vetiver grass hedgerows & 660.0 \\
\hline CV $(\%)$ & 4.53 \\
\hline LSD & 434.6 \\
\hline
\end{tabular}

CV: Coefficient of Variation; LSD: List Significant of Difference

\section{CONCLUSION AND RECOMMENDATIONS}

This study revealed that, the established Vetiver grass hedgerows were effective for soil and water conservation. Cropland treated with Vetiver hedgerows were developed to bench terrace that reduce the velocity of runoff, the aforementioned effect of the hedgerows reduces soil erosion. Thus, improves some of the soil properties, yield and slope of cropland treated with Vetiver hedgerows as compared to adjacent cropland without Vetiver hedgerows. Soil organic carbon and available phosphorus was significantly higher for croplands treated with Vetiver grass hedgerows as compared to control, while soil $\mathrm{pH}$, exchangeable acidity, available potassium and total nitrogen were not showed significant difference among croplands. Furthermore, mean of crop yield was higher for cropland with Vetiver grass hedgerows than control.

Therefore, it is essential to aware the farmers and treat degraded farm land with Vetiver hedgerows to improve productive capacity of the land. Moreover, regular maintenance shall be required to encourage rapid development of bench terrace through facilitating the deposition of eroded soil between inter-bund zones to reduce soil erosion. The practice is environmentally friendly and easy to establish, therefore; it is crucial to promote the practice to other similar areas to conserve soil and water. Further investigation of the effectiveness of the grass hedgerow with respect of landscape position and effect of the grass on carbon sequestration potential is encouraged.

\section{ACKNOWLEDGMENT}

The authors would like to acknowledge Jimma Agriculture Research Center for the financial support and Jimma Agricultural Research soil and plant tissue laboratory for their support by analyzing soil samples at time.

\section{REFERENCES}

[1] H. Hurni, W.A. Berhe, P. Chadhokar, D. Daniel, Z. Gete, M. Grunder, G. Kassaye, Soil and Water Conservation in Ethiopia: Guidelines for Development Agents. Second edition. Bern, Switzerland: Centre for Development and Environment (CDE), University of Bern, with Bern Open Publishing (BOP) 2016, pp.134. 
[2] Kirui, O., Impact of land degradation on household poverty: evidence from a panel data simultaneous equation model. Invited paper presented at the 5th International Conference of the African Association of Agricultural Economists, Addis Ababa, Ethiopia, September 23-26, (2016).

[3] Nyssen, J., Poesen, J., Moeyersons, J., Haile, M. and Deckers, J., Dynamics of soil erosion rates and controlling factors in the Northern Ethiopian Highlands-towards a sediment budget. Earth surface processes and landforms, 33(5): 695-711 (2008).

[4] Molla T., and Sisheber B., Estimating soil erosion risk and evaluating erosion control measures for soil conservation planning at Koga watershed in the highlands of Ethiopia. Solid Earth, 8(1): 13. (2017).

[5] Gashaw T., Tulu T. and Argaw M., Erosion risk assessment for prioritization of conservation measures in Geleda watershed, Blue Nile basin, Ethiopia. Environmental Systems Research, 6(1): 1 (2017).

[6] Adugna A., Abegaz A. and Cerda A., Soil erosion assessment and control in Northeast Wollega, Ethiopia. Solid Earth Discussions, 7(4): 3511-3540 (2015).

[7] Tesfaye, G., Debebe, Y. and Yakob, T., Adoption and Effect of Vetiver Grass (Vetiveria zizanioides) on soil Erosion in Somodo Watershed, South-Western Ethiopia. Open Access Library Journal, 5: e4431. https://doi.org/10.4236/oalib.1104431, 5 (2018).

[8] Tesfu K. and Zebene M., Effect of Different Cover Crops on Runoff and Soil Loss. Proceeding: Workshop organized by UNESCO chair in water resources entitled "International Sediment Initiatives Conference (ISIC)", Nov. 12-15, Khartoum (2006).

[9] R. P. C. Morgan, 2005. Soil Erosion and Conservation. Third edition, National Soil Resources Institute, Cranfield University, Blackwell publishing, Oxford. pp 1-24 (2005).

[10] Tulu, T., Soil and water conservation for sustainable agriculture, Mega publishing and distribution P.L.C, Addis Ababa (2011).

[11] Guerra A. J. T., Fullen M. A., Jorge M. C. O., Bezerra J. F. R., Shokr M. S., Slope processes, mass movement and soil erosion: A review. Pedosphere, 27(1): 27-41(2017).

[12] Wolka K. Moges A. and Yimer F., Effects of level soil bunds and stone bunds on soil properties and its implications for crop production: the case of Bokole watershed, Dawuro zone, Southern Ethiopia. Agricultural Sciences, 2(3): 357-363 (2011).

[13] Gashaw T., Bantider A. and Silassie H.G., Land degradation in Ethiopia: causes, impacts and rehabilitation techniques. Journal of Environment and Earth Science, 4(9): 98-104 (2014).

[14] Grimshaw R., The Vetiver system. First National Indian Vetiver Workshop. The Vetiver International. Kochi, India, pp. 21-23 (2008).

[15] Singh M., Guleria N., Rao E. P., Goswami P., Efficient C sequestration and benefits of medicinal Vetiver cropping in tropical regions. Agronomy for Sustainable Development, Springer Verlag/EDP Sciences/INRA. 34 (3): 603-607 (2014).

[16] Rao E.P., Akshata S., Gopinath C.T., Ravindra N.S., Hebbar A. and Prasad N., Vetiver Production for Small Farmers in India. In Sustainable Agriculture Reviews, Springer, Cham, pp. 337-355 (2015).

[17] Gnansounou E., Alves C.M., Raman J.K., Multiple applications of Vetiver grass - a review, International Journal of Environmental Science, 2: 125-141 (2017).

[18] Truong P., Vetiver grass for mine site rehabilitation and reclamation. In: Proceedings of Remade Lands International Conference, Fremantle, Australia; November; pp. 85-86 (2000).

[19] Joseph J.K., Haridasan A., Akhildev K. and Pradeep Kumar A.P., Applications of Vetiver Grass (Chrysopogon zizanioides) in Eco System Based Disaster Risk Reduction Studies from Kerala State of India. Journal of Geography and Natural Disasters, 7(192): 2167-0587 (2017).

[20] Kebede T. and Yaekob T. Research and development of Vetiver grass (Vetiver zizanioides, L.) in Ethiopia. Jimma Research Center, Ethiopia (2009).

[21] Mekonnen A. Erosion control in agricultural areas: an Ethiopian perspective. GTZ International Food security Program. Ethiopia (2000).

[22] WAO (woreda agricultural office), Haru woreda agricultural office (2017).

[23] CSA (Central Statistical Agency), Summary and statistical report of the 2007 population and housing census: Population Size by Age and Sex (2007).

[24] CSA, Central Statistical Agency Agricultural Sample Survey 2016/2017 (2009 E.C.) Volume I Report On Area And Production Of Major Crops (Private Peasant Holdings, Meher Season), Addis Ababa, April, (2017). 
Effect of Vetiver Grass (Vetiver Zizanodes) Hedgerows on Selected Soil Properties and Crop Yield on Farm Land at Haru District, Western Ethiopia

[25] Jacson M.L., Soil chemical Analysis. Prentice Hall of Indea, Private Ltd. New Delhi (1958).

[26] Bray R.H. and Kurtz L.T., Determination of total, organic, and available forms of phosphorus in soils. Soil science, 59(1): 39-46 (1945).

[27] Walkley A. and Black I. A., An examination of the digestion method for determining soil organic matter and a proposed modification of the chromic acid titration method. Soil Science, 37: 29-38 (1934).

[28] Bremner J.M. and Mulvaney C.S., Nitrogen-Total 1. Methods of soil analysis. Part 2. Chemical and microbiological properties, (methodsofsoilan2), American Society of Agronomy, Madison, pp. 595-624 (1982).

[29] McLean O., 1965. Aluminum. In: C.A. Black (ed.), Methods of Soil Analysis. Agronomy, No.9. Part II. American Society Agronomy, Madison, Wisconsin. USA, pp 978 - 998.

[30] Champman D., Cation exchange capacity by ammonium saturation. In: black, C.A., L.E., Ensminger and F.E., Clark (Eds.). Method of soil analysis. American Society of Agronomy. Madison Wisconsin, USA. PP. 891- 901 (1965).

[31]Elias, E., Soil of the Ethiopian Highlands: Geomorphology and properties. Capacity Building for Scaling Up of Evidence-Based Best Practices for Increased Agricultural Production in Ethiopia (CASCAPE), ALTERA, Wageningen University and Research Centre (Wageningen UR). The Netherlands, 385 (2016).

[32] Gesesse A., Balemi T., Natarajan P. and Amha Y., Effect of Vetiver Grass Headges in Maintaining Soil Fertility and Productivity at Anno Agro Industry Farm, Gobu Sayo District, Oromiya Region, Ethiopia. Journal of Science and Sustainable Development (JSSD), 1, 37-49, (2013).

[33] Obsa A, Dereje A, Tesfahun M. Evaluation of Vetiver Grass (Vetiver zizanodes) Potential to Soil Erosion Control at Assosa, Benishangul Gumuz, Ethiopia. Int J Environ Sci Nat Res.; 16(1), (2019)

[34] Babalola O., Jimba S.C., Maduakolam O. and Dada O.A., Use of Vetiver grass for soil and water conservation in Nigeria. In Proceedings of the third international conference on Vetiver and Exhibition. Guangzhou, China pp. 293-309 (2003).

Citation: Leta Hailu, "Effect of Vetiver Grass (Vetiver Zizanodes) Hedgerows on Selected Soil Properties and Crop Yield on Farm Land at Haru District, Western Ethiopia” International Journal of Research Studies in Agricultural Sciences (IJRSAS), 2020; 6(5), pp. 35-41, http://dx.doi.org/ 10.20431/2454-6224.0605005

Copyright: (C) 2020 Authors. This is an open-access article distributed under the terms of the Creative Commons Attribution License, which permits unrestricted use, distribution, and reproduction in any medium, provided the original author and source are credited. 